DOI: 10.20472/IAC.2019.048.044

\title{
SOOBRAMONEY PENCELIAH
}

Durban University of Technology, South Africa

FREEDOM CLEMENT VEZI

Durban University of Technology, South Africa

\section{THE INFLUENCE OF MARKETING COMMUNICATION ON STUDENTS' DECISIONS TO ENROL AT TECHNICAL VOCATIONAL EDUCATION AND TRAINING COLLEGES}

\begin{abstract}
:
Marketing higher education is a growing field of expertise in many developing countries. However, little research has been done on marketing Technical Vocational Education and Training (TVET) Colleges in South Africa. Evidence suggests that it may suffer from a lack of expertise to provide direction to the practical aspects of marketing TVET Colleges. Most of the marketing practices of Higher Education are underdeveloped and lack a strategic focus when it comes to Technical Vocational Education and Training. For TVET Colleges marketing communication plays an important role in students' recruitment.
\end{abstract}

The purpose of this paper is to analyse the influence of marketing communication towards students' decision to enrol at Technical Vocational Education and Training Colleges. The study was conducted in KwaZulu-Natal, South Africa, where the targeted TVET colleges are based. This is a quantitative, descriptive, and cross-sectional study conducted among a sample of 400 TVET College students.

The results of this study reveal the need for marketing communication in TVET Colleges to be addressed urgently in order to improve public perception and enrolment rates at TVET Colleges. Both the students and TVET Colleges will benefit from the study because marketing and communication as a source of information will assist when selecting a college of choice. In addition, this will assist TVET Colleges in the selection of appropriate marketing communication media to enable proper allocation of marketing budget and resources.

The findings of this study will then act as guidelines to determine a more appropriate marketing communication strategy to improve the public perceptions of TVET Colleges to make TVET Colleges a students' first choice.

\section{Keywords:}

TVET Colleges, student perception, marketing communication 